\title{
PENGARUH PERSEPSI KUALITAS PELAYANAN E-COMMERCE TERHADAP KE PUASAN PELANGGAN, KE PERCAYAAN DAN LOYALITAS PADA PRODUK FASHION
}

\author{
Oktania Setyaningsih \\ Magister Manajemen \\ Fakultas Ekonomi dan Bisnis \\ Universitas Sebelas Maret
}

\begin{abstract}
The specifics goal of study are namely to explain the influence of (1) Quality of Service Satisfaction, (2) Service Quality of the Trust, (3) Service Quality to Loyalty (4) Satisfaction to Loyalty, and (5) of the Loyalty Trust. The population in this study are all consumers who had conducted the transaction in Saqina.com. The number of respondents was used a sample of 250 respondents.

The population in this study are all consumers who had conducted the transaction in Saqina.com. The number of respondents was used a sample of 250 respondents. The results showed a significant effect of interaction between variables in the four effects, namely: (1) Quality of Service Satisfaction ( $C R=$ 5578), (2) Quality of Service Trust $(C R=5164)$, (3) Satisfaction to Loyalty ( $C R=$ 2009 ), (4) of the Loyalty Trust ( $C R=2144)$, whereas no significant effect of the Service Quality to Loyalty ( $C R=-1766)$, calculation results also showed that the total effect of Trust is a mediating variable between Service Quality to Loyalty.

As for the stimulus to do the marketing, among others, are (1) maintain a COD service to increase customer trust, (2) optimize customer satisfaction through improved service, the information presented better organized so that consumers more easily and comfortably in the transaction, (3) Provide a stage 'order tracking' for customers, so customers can monitor the extent to which the development of product orders. For future studies are expected to (1) Develop more variables studied, (2) Perform the comparison e-commerce both in Indonesia and internationally.
\end{abstract}

Key words: service quality, customer satisfaction, customer trust, customer loyalty.

\section{ABSTRAK}

Secara spesifik, terdapat tujuan yang diharapkan, yaitu menjelaskan pengaruh (1) Service Quality terhadap Satisfaction, (2) Service Quality terhadap Trust, (3) Service Quality terhadap Loyalty (4) Satisfaction terhadap Loyalty, (5) Trust terhadap Loyalty.

Populasi dalam penelitian ini adalah semua konsumen yang pernah melakukan transaksi di Saqina.com. Jumlah responden yang digunakan sebagai 
sampel adalah sebanyak 250 responden. Hasil penelitian menunjukkan pengaruh signifikan antar variabel dalam empat interaksi pengaruh, yaitu : (1) Kualitas Pelayanan terhadap Kepuasan ( $C R=5.578),(2)$ Kualitas Pelayanan terhadap Kepercayaan $(C R=5.164)$, (3) Kepuasan terhadap Loyalitas $(C R=2.009)$, (4) Kepercayaan terhadap Loyalitas $(C R=2.144)$, sedangkan pengaruh yang tidak signifikan yaitu Kualitas Pelayanan terhadap Loyalitas ( $C R=-1.766)$, hasil perhitungan total effect juga menunjukkan bahwa Kepercayaan $(\Upsilon=0,814)$ merupakan variabel mediasi antara Kualitas Pelayanan terhadap Loyalitas.

Stimulus pemasaran yang dapat dilakukan antara lain adalah (1) mempertahankan pelayanan COD untuk meningkatkan kepercayaan pelanggan, (2) mengoptimalkan kepuasan pelanggan melalui peningkatan pelayanan, informasi-informasi yang disajikan lebih terorganisir sehingga konsumen lebih mudah dan nyaman dalam bertransaksi, (3) Menyediakan tahap 'tracking order' bagi pelanggan, sehingga pelanggan dapat memantau sejauh mana perkembangan pesanan produk. Bagi penelitian selanjutnya diharapkan (1) Mengembangkan lebih banyak variabel yang diteliti, (2) Melakukan perbandingan e-commerce baik di Indonesia maupun internasional.

Kata kunci: kualitas pelayanan, kepuasan pelanggan, kepercayaan pelanggan, loyalitas pelanggan.

Saat ini internet sudah menjadi bagian dari kehidupan sehari- hari, di rumah, di kantor, di kafe, di bandara atau di manapun, sebagian besar di antara kita selalu menyempatkan mengakses internet. Internet adalah jalan yang memungkinkan membantu untuk melakukan promosi dan memasarkan produk dan layanan yang dimiliki seseorang atau perusahaan. Internet menyediakan sebuah mekanisme yang memungkinkan konsep dasar dengan web misalnya untuk mengikat pelanggan lebih dekat lagi. Pesatnya perkembangan industri e-commerce atau perdagangan elektronik, semakin memacu persaingan antara para pelaku bisnis di dunia maya, Untuk dapat sukses pada ekonomi online diperlukan strategi yang baru, kemitraan yang baru dan cara yang baru dalam menjalankan bisnis.

Booming perusahaan-perusahaan dotcom di dunia ikut mengungkit kehadiran e-commerce di Indonesia dimana penggunaan internet juga ikut mempengaruhi gaya operasi perusahaan yang selama ini beroperasi secara konvensional, seperti pada perusahaanperusahaan yang melayani sektor ritel tak terkecuali pada objek penelitian ini yaitu sektor industri pakaian di web saqina.com. Hal ini menjadi penting dalam lingkungan global e-commerce tidak terkecuali di Saqina sendiri yang sudah berkecimpung selama kurang lebih 6 tahun dalam ecommerce, maka dari itu kualitas pelayanan online dan kepuasan juga menjadi isu penting dalam penelitian ini.

Memang, keberhasilan dari beberapa situs web terkenal dapat dikaitkan bagian dari kemampuan mereka untuk mempertahankan loyalitas pelanggan. Misalnya kesuksesan Amazon.com, situs online terkemuka penjualan buku, misalnya, dihubungkan dengan tingkat loyalitas tinggi pelanggan, dengan $66 \%$ dari pembelian yang dilakukan oleh pelanggan kembali [The Economist 2000].

Studi ini merupakan pengembangan dari penelitian yang dilakukan oleh Norizam et al., (2010) yang berjudul 'The Effect of Perceived Service Quality 
Dimensions on Customer Satisfaction,trust, and loyalty in e-commerce setting : A Cross Cultural Analysis yang bertujuan menginvestigasi kualitas pelayanan yang mempengaruhi kepuasan konsumen dan kepercayaan yang dapat menciptakan diantara konsumen Malaysia dan Qatari ; serta penelitian yang dilakukan oleh Javad (2009) yang berjudul 'Influential Factors of Customer e-Loyalty in Iranian Stores yang bertujuan untuk mencapai pemahaman mendalam bagaimana menciptakan dan mempertahankan loyalitas konsumen web dari perspektif perusahaan.

Tujuan dari studi ini yaitu : mengetahui Kualitas Pelayanan Saqina.com yang mempengaruhi Kepuasan pelanggan ; mengetahui Kualitas Pelayanan Saqina.com sehingga mempengaruhi Kepercayaan pelanggan ; memahami Kualitas Pelayanan di Saqina.com yang berpengaruh terhadap Loyalitas pelanggan ; memahami Kepuasan pelanggan Saqina.com yang mempengaruhi Loyalitas dan memahami Kepercayaan pelanggan sehingga berpengaruh terhadap Loyalitas.

\section{TELAAH PUSTAKA}

\section{Kualitas Pelayanan ( Senvice Quality )}

Gronroos (2001, dalam Mohammad et al., 2009) menyatakan bahwa secara tradisional, kualitas pelayanan telah dikonseptualisasikan sebagai perbedaan antara harapan pelanggan mengenai layanan yang akan diterima dan persepsi layanan yang diterima. Parasuraman et al., (1988) mengidentifikasi lima dimensi kualitas pelayanan (yaitu keandalan, daya tanggap, jaminan, empati, dan bukti fisik) yang memiliki pranala karakteristik layanan tertentu untuk harapan konsumen.

1. Tangibles : fasilitas fisik, peralatan dan penampilan personil;

2. Empati : kepedulian, perhatian individual;

3. Assurance - pengetahuan dan kesopanan karyawan dan kemampuan mereka untuk menyampaikan kepercayaan dan keyakinan

4. Reliabilitas - kemampuan untuk melakukan layanan yang dijanjikan dan keakuratan, dan

5. Responsif - kemauan untuk membantu pelanggan dan memberikan layanan yang cepat.

\section{Kepercayaan (Trust)}

Dalam bisnis, kepercayaan dipandang sebagai salah satu anteseden stabil yang paling relevan dan hubungan kolaboratif. Para peneliti telah menetapkan bahwa kepercayaan adalah penting untuk membangun dan memelihara hubungan jangka panjang menurut Rousseau et al., (2000, dalam Mohammad et al., 2009). Morgan dan Hunt (1994) menyatakan bahwa kepercayaan ada hanya jika salah satu pihak memiliki keyakinan dalam pertukaran sebuah keandalan dan integritas mitra. Definisi yang diberikan oleh Morgan dan Hunt (1994) telah digunakan untuk penelitian ini.

\section{Kepuasan (Satisfaction)}

Interpretasi yang paling umum yang diperoleh dari berbagai penulis yang mencerminkan gagasan bahwa kepuasan adalah perasaan dimana hasil dari proses evaluasi apa yang telah diterima terhadap apa yang diharapkan, termasuk keputusan pembelian itu sendiri dan kebutuhan dan keinginan yang terkait dengan pembelian (Kotler dan Armstrong , 1996). Bitner \& Zeithaml (2003) menyatakan bahwa kepuasan adalah evaluasi pelanggan terhadap suatu produk atau jasa dalam hal apakah bahwa produk atau jasa tersebut telah memenuhi kebutuhan dan harapan mereka.

Menurut Boselie, Hesselink, dan Wiele (2002, dalam Mohammad et al., 2009) kepuasan adalah positif, pernyataan afektif yang dihasilkan dari penilaian dari semua aspek hubungan kerja satu pihak dengan yang lain. Definisi yang diberikan 
oleh Boselie et al., (2002, dalam Mohammad et al., 2009) digunakan untuk penelitian ini.

\section{Kesetiaan (Loyalty)}

Seperti yang diidentifikasi oleh para peneliti bahwa loyalitas pelanggan sebagai konstruksi yang terdiri dari baik sikap dan perilaku pelanggan. Di sisi lain, aspek perilaku loyalitas pelanggan merepresentasikan- mengulang pembelian aktual produk atau jasa mencakup pembelian lebih lanjut dan produk atau jasa yang berbeda dari perusahaan yang sama, merekomendasikan perusahaan untuk orang lain, dan mencerminkan kemungkinan pilihan jangka panjang untuk merek (Feick, Lee, dan Lee, 2001). Dapat disimpulkan bahwa loyalitas pelanggan mengekspresikan perilaku yang dimaksudkan berkaitan dengan produk atau jasa atau untuk perusahaan. Pearson (1996) mendefinisikan loyalitas pelanggan sebagai pola pikir pelanggan yang bersikap baik terhadap perusahaan, berkomitmen untuk membeli kembali produk I jasa perusahaan, dan merekomendasikan produk / jasa kepada orang lain. Peneliti telah menggunakan definisi Pearson (1996) untuk penelitian ini.

\section{Model Ribbink (Ribbink Model)}

Menurut Ribbink et al., (2004) yang menyelidiki evaluasi pelanggan layanan elektronik dan e-trust dalam menjelaskan loyalitas pelanggan untuk pengecer online. Lebih spesifik lagi, peran mediasi dari etrust antara kualitas dan loyalitas dimodelkan, di samping itu adalah untuk menyelidiki peran evaluasi pelanggan layanan dan e-trust dalam menjelaskan loyalitas pelanggan untuk pengecer online. Lebih khusus lagi, peran mediasi kepercayaan antara kualitas layanan dan loyalitas dimodelkan.

Kepuasan juga memberikan kontribusi terhadap loyalitas, dapat ditingkatkan secara substansial melalui layanan yang menarik bagi pengguna sertu kemudahan operasional. Ilustrasi model Ribbink adalah sebagai berikut:

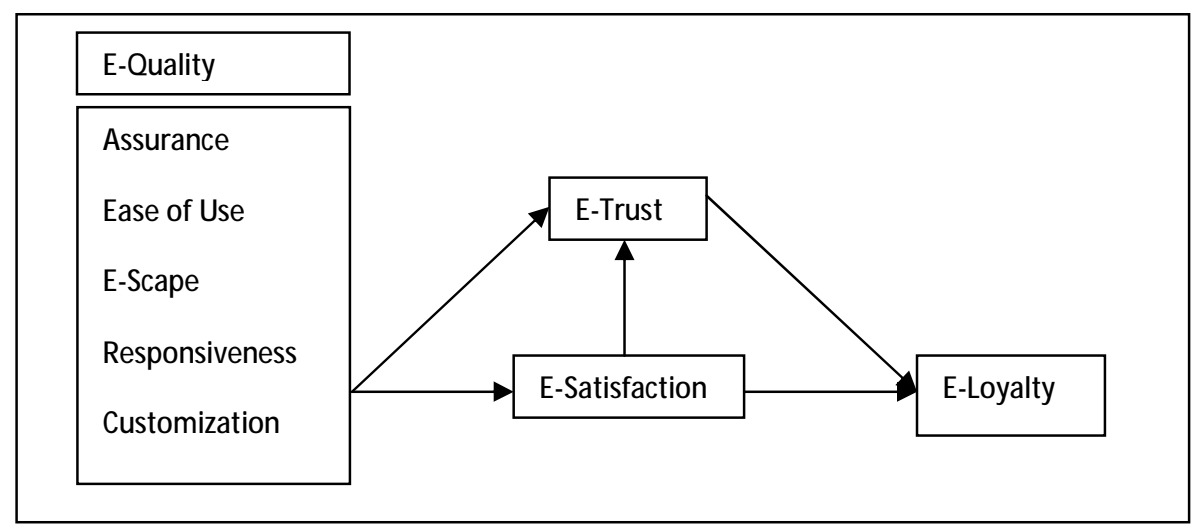

Sumber : Ribbink et al., (2004)

Gambar 1. Ribbink Model 


\section{Pengaruh Kualitas Pelayanan Terhadap Kepuasan Pelanggan}

Selama beberapa tahun terakhir telah terjadi penekanan tinggi pada kualitas pelayanan dan kepuasan pelanggan dalam bisnis dan akademisi. Sureshchandar et al., (2003) mengidentifikasi bahwa ada pengaruh yang kuat antara kualitas pelayanan dan kepuasan pelanggan sementara menekankan bahwa keduanya secara konseptual berbeda konstruksi dari sudut pandang pelanggan. Spreng dan Mackoy (1996) juga menunjukkan bahwa kualitas pelayanan mengarah pada kepuasan pelanggan ketika bekerja pada model yang dikembangkan oleh Oliver (1997). Dalam penelitian yang dilakukan oleh Ribbink et al., (2004) mengungkapkan bahwa hubungan ini juga ada dalam industri e-commerce.

H1: Kualitas Pelayanan dalam industri e-commerce berpengaruh secara positif terhadap Kepuasan Pelanggan.

\section{Pengaruh Kualitas Pelayanan Terhadap Kepercayaan Pelanggan}

Kepercayaan pelanggan itu sendiri adalah produk dari pelayanan pelanggan yang unggul (Reichheld, dan Schefter , 2000). Alasan teoritis untuk itu kembali ke penjelasan Luhmann's (1979) dan Blau's (1964) bahwa kepercayaan dibangun ketika pihak terpercaya berperilaku yang dapat diterima secara sosial yang sesuai dengan apa yang diharapkan dari pihak terpercaya, dan sebaliknya, kepercayaan berkurang ketika pihak terpercaya tidak berperilaku sesuai tanpa alasan yang baik. Karena kualitas pelayanan adalah sesuatu yang pelanggan harapkan secara umum bahwa vendor menyediakan mereka dengan layanan berkualitas tinggi yang harus membangun kepercayaan pelanggan, studi penelitian laporan terbaru bahwa hal itu juga dengan pelanggan dari vendor online (Reichheld, dan Schefter, 2000).

Teori menunjukkan bahwa kepercayaan yang memainkan peran sentral ini melalui dua mekanisme yang mungkin: (1) metode pengurangan kompleksitas sosial (Gefen, 2000), seperti yang dijelaskan di atas, dan (2) mengurangi risiko dianggap melakukan bisnis dengan vendor (Jarvenpaa, dan Tractinsky, 1999). Yang terakhir, menyoroti pentingnya risiko dianggap sebagai penghambat dalam melakukan bisnis di web, dan kepercayaan sebagai risiko mengurangi mekanisme.

Dengan kata lain, pendekatan kepercayaan memandang kepercayaan sebagai pemampu psikologis langsung dari bisnis online dengan mengurangi ketidakpastian sosial yang luar biasa dinyatakan, pendekatan kedua menekankan konsekuensi menghambat risiko. Tidak diragukan lagi, ada risiko tersebut dalam lingkungan online, karena ada aktivitas perdagangan, kecuali bahwa risiko ini lebih disebutkan online karena pelanggan tidak terlibat dengan agen manusia dan tidak bisa karena mengandalkan isyarat, seperti bahasa tubuh dan intonasi, untuk menilai apakah vendor tersebut dapat dipercaya (Reichheld, dan Schefter, 2000).

Kepercayaan, secara psikologis mengurangi ancaman bahwa pihak lain dapat ikut serta dalam perilaku oportunistik, mengurangi persepsi risiko. Risiko, didalamnya sendiri, menghambat aktivitas online (Jarvenpaa, dan Tractinsky, 2000).

H2: Kualitas Pelayanan e-commerce berpengaruh positif terhadap Kepercayaan Pelanggan. 
3. Pengaruh Kualitas Pelayanan Terhadap Loyalitas Pelanggan

Dalam berbagai studi hubungan antara kualitas pelayanan dan preferensi loyalitas pelanggan telah diteliti oleh Boulding, Kalra, Staelin, dan Zeithaml, (1993, dalam Srini et al., 2002). Dalam studi mereka Cronin dan Taylor (1992) difokuskan hanya pada niat pembelian kembali, sedangkan Boulding et al., (1993, dalam Srini et al., 2002 ) difokuskan pada elemen pembelian kembali serta kesediaan untuk merekomendasikan. Dalam studi oleh Cronin dan Taylor kualitas pelayanan tampaknya tidak memiliki efek (positif) signifikan terhadap niat pembelian kembali (berbeda dengan dampak positif yang signifikan kepuasan terhadap niat pembelian kembali), sedangkan Boulding et al., (1993, dalam Srini et al., 2002) menemukan hubungan positif antara kualitas pelayanan dan niat pembelian kembali dan kesediaan untuk merekomendasikan.

H3: Kualitas Pelayanan yang dirasakan Pelanggan memiliki pengaruh positif terhadap Loyalitas pelanggan.

\section{Pengaruh Kepercayaan Terhadap Loyalitas Pelanggan}

Sejumlah

menganjurkan merupakan peneliti bahwa kepercayaan dasar dalam mengembangkan loyalitas pelanggan (Moorman, Deshpande, dan Zaltman, (1993, dalam Mohammad et al., 2009).
Pentingnya kepercayaan dalam menjelaskan loyalitas juga didukung oleh penulis seperti Lim dan Razzaque (1997), Garbarino dan Johnson (1999), Chaudhuri dan Holbrook (2001), Singh dan Sirdeshmukh (2000), dan Sirdeshmukh, Singh, dan Sabol (2002).

Namun, dalam pasar kurangnya kepercayaan dengan alternatif yang cocok mungkin mengakibatkan loyalitas negatif. Corbitt, Thanasankit, dan Yi (2003) telah menunjukkan bahwa efek positif yang kuat kepercayaan terhadap loyalitas pelanggan pada kasus sektor telekomunikasi.

H4: Kepercayaan memiliki pengaruh terhadap Loyalitas pelanggan.

\section{Pengaruh Kepuasan Terhadap Loyalitas Pelanggan}

Beberapa penulis seperti Anderson, dan Sullivan, (1993, dalam Mohammad et al., 2009) telah menemukan korelasi positif antara kepuasan dan loyalitas pelanggan. Sejumlah penelitian di sektor jasa juga telah divalidasi secara empiris hubungan antara kepuasan dan niat perilaku seperti retensi pelanggan dan word of mouth.

Hart dan Johnson (1999) telah menambahkan bahwa salah satu kondisi loyalitas pelanggan yang benar adalah kepuasan total. Oleh karena itu, peneliti memiliki hipotesis sebagai berikut:

H5: Kepuasan pelanggan memiliki pengaruh positif terhadap Loyalitas pelanggan. 


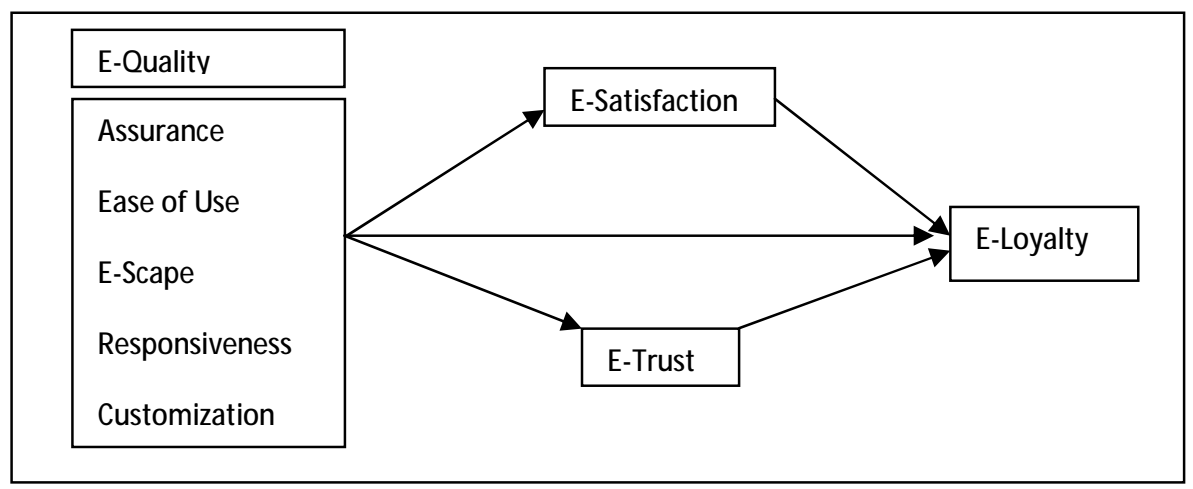

Sumber : Norizam et al., (2010) and Javad (2009)

Gambar 2. Kerangka Penelitian

\section{METODE PENELITIAN}

\section{Populasi dan Sampel}

Populasi dalam penelitian ini adalah semua orang yang pernah melakukan transaksi atau pembelian di Saqina.com. Dalam penelitian ini sampel yang digunakan berjumlah 250 responden. Hal ini didasarkan pada hasil jumlah perkalian indikator sebanyak 46 item dengan 5 yaitu 230 (berpedoman pada poin d) dan sisanya (20) untuk mengantisipasi jika terdapat data yang rusak. Dengan begitu pertimbangan pada aspek kualitas responden yang lebih diutamakan dan aspek kriteria minimal kelayakan dalam penganalisaan data sesuai dengan metode statistik. Teknik pengambilan sampel dengan purposive sampling dengan kriteria sebagai berikut:

1. Pernah melakukan transaksi atau pembelian di saqina.com minimal 2 kali
2. Berkeinginan untuk membeli kembali produk-produk Saqina.com

3. Responden mempunyai kesempatan sekali dalam pengisian kuisioner,

4. Responden bebas menerima atau menolak survei, dan tidak ada ikatan kekerabatan, intimidasi atau hadiah dalam bentuk apapun yang dapat menurunkan derajat keyakinan terhadap kualitas data yang diperoleh.

\section{HASI L DAN PEMBAHASAN}

\section{Analisis Statistik Deskriptif}

Data responden menunjukkan bahwa responden dalam penelitian ini mayoritas adalah berjenis kelamin perempuan dengan persentase $75,2 \%$, dengan rentang usia 21 - 30 tahun sebesar $43,2 \%$ dan sebagian besar berpendidikan SMA atau sederajat sejumlah $66 \%$. 
Tabel 1. Distribusi Tanggapan Responden Terhadap Kualitas Pelayanan, Kepuasan, Kepercayaan dan Loyalitas

\begin{tabular}{|l|l|l|l|l|l|l|}
\hline $\begin{array}{c}\text { Distribusi Total } \\
\text { Tanggapan Responden } \\
(\%)\end{array}$ & \multicolumn{1}{|c|}{ SS } & S & CS & TS & STS & $\begin{array}{c}\text { Total } \\
\text { (\%) }\end{array}$ \\
\hline Variabel : & \multicolumn{7}{|l|}{} \\
\hline Kualitas Pelayanan & 0.017 & 44.32 & 52.73 & 2.89 & 0.043 & $\mathbf{1 0 0}$ \\
\hline Kepuasan & 1.2 & 46.64 & 49.52 & 2.64 & - & $\mathbf{1 0 0}$ \\
\hline Kepercayaan & 7.04 & 50.48 & 40.4 & 2.08 & - & $\mathbf{1 0 0}$ \\
\hline Loyalitas & 4.31 & 55.11 & 38.85 & 1.73 & - & $\mathbf{1 0 0}$ \\
\hline
\end{tabular}

Sumber: data primer diolah, 2012

1) Berdasarkan data dari Tabel 1 variabel Kualitas Pelayanan diatas menunjukkan bahwa mayoritas responden menjawab "Cukup Setuju" yaitu sebesar 52,73\% atas beberapa item pernyataan mengenai kualitas pelayanan yang diberikan oleh Saqina.com. Hal ini menunjukkan sebagian besar pelanggan merasa bahwa pelayanan yang selama ini diberikan oleh Saqina.com cukup berkualitas.

2) Berdasarkan data dari Tabel 1 variabel Kepuasan diatas menunjukkan bahwa mayoritas responden menjawab "Cukup Setuju" yaitu sebesar $49,52 \%$ atas beberapa item pernyataan mengenai kepuasan yang dirasakan oleh pelanggan Saqina.com. $\mathrm{Hal}$ ini menunjukkan sebagian besar pelanggan merasa cukup puas dengan Saqina.com.

3) Berdasarkan data dari Tabel 1 variabel Kepercayaan diatas menunjukkan bahwa mayoritas responden menjawab "Setuju" sebesar 50,48\% atas beberapa item pernyataan mengenai kepercayaan oleh pelanggan Saqina.com. Hal ini menunjukkan sebagian besar pelanggan percaya dengan Saqina.com.

4) Berdasarkan data dari Tabel 1 variabel Loyalitas diatas menunjukkan bahwa mayoritas menjawab "Setuju" sebesar $55,11 \%$ responden atas beberapa item pernyataan mengenai loyalitas pelanggan Saqina.com. $\mathrm{Hal}$ ini menunjukkan sebagian besar pelanggan memang loyal atau setia terhadap Saqina.com.

\section{Analisis Data}

Uji validitas dilakukan dengan program Amos 18 dan semua indikator dalam penelitian ini menghasilkan nilai estimasi dengan C.R. lebih besar dari dua kali standar errornya. Maka dapat disimpulkan bahwa indikator variabel penelitian yang digunakan adalah valid semua sehingga layak digunakan sebagai instrument dalam mengukur kualitas pelayanan, kepuasan, kepercayaan dan loyalitas. Sedangkan uji reabilitas dengan nilai batas yang digunakan adalah 0,70 (Nunally dan Bernstein, 1994). Semua variabel dalam penelitian menunjukkan construct realibility $>0,70$.

Berdasarkan hasil pengujian normalitas diperoleh hasil bahwa secara univariate terdapat beberapa item yang mengindikasikan tidak terdistribusi normal karena memiliki nilai $C . R>2,58$ yaitu $L 1$, R2, T5, dan T2, akan tetapi tidak ada yang memiliki nilai C.R skewness dan C.R. kurtosis yang $>2,58$. Pengujian normalitas secara multivariate sebesar 2,868 yang menandakan bahwa data dalam penelitian ini terdistribusi normal secara multivariate. Berdasarkan hasil pengujian outlier dapat diketahui indikasi outlier masih dapat diterima (tidak ada nilai observasi yang memiliki nilai probabilitas p1 dan p2 dibawah 0,05). Sehingga dapat dikatakan 
dalam penelitian ini tidak ada observasi yang mengalami masalah outlier.

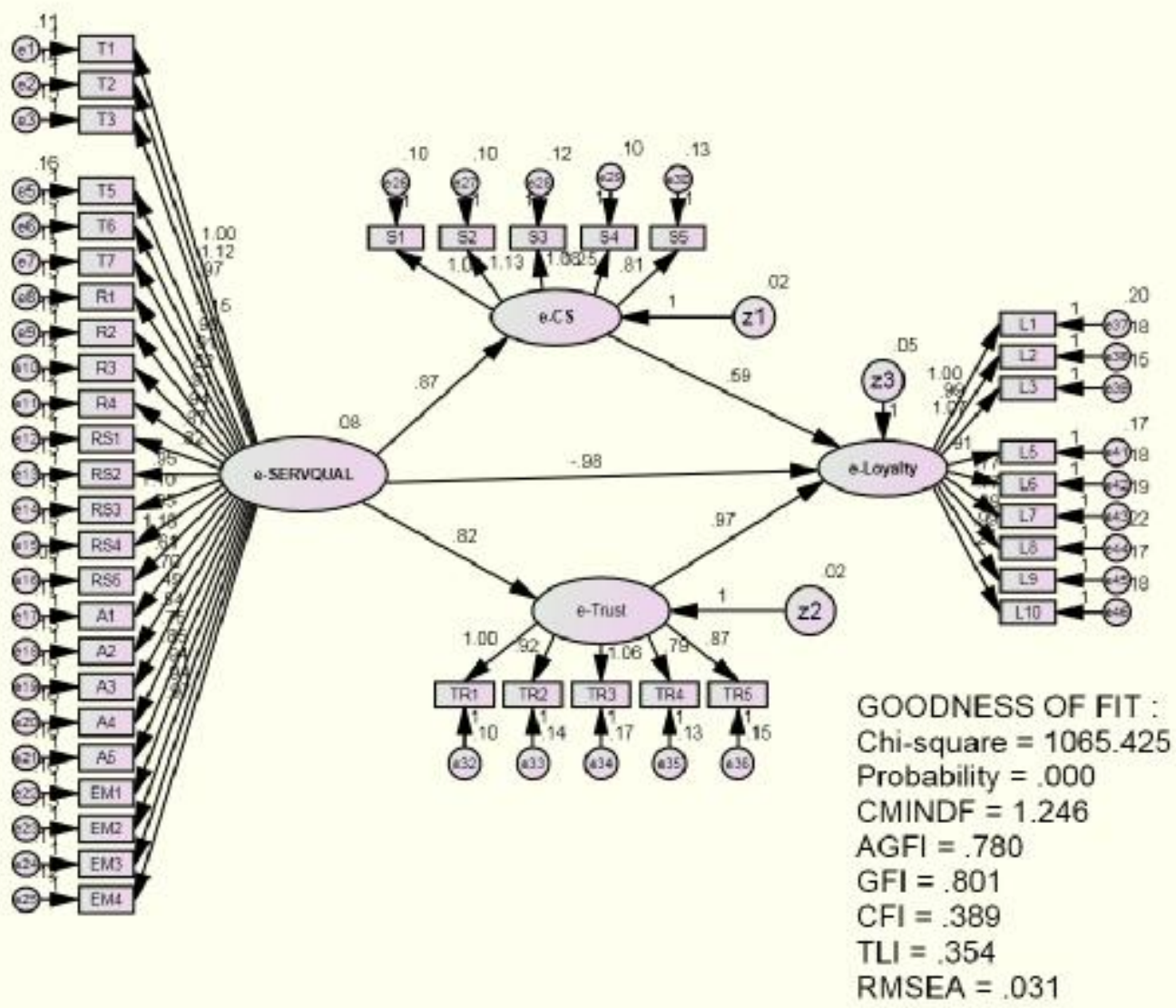

Gambar 3. Model Struktural (SEM)

Dikarenakan sebelumnya model indikator melalui "modification dinyatakan tidak fit maka modifikasi model indices"nya. Adapun hasil modifikasi harus dilakukan dengan cara model selengkapnya adalah sebagai mengkorelasikan nilai measurement error berikut: 


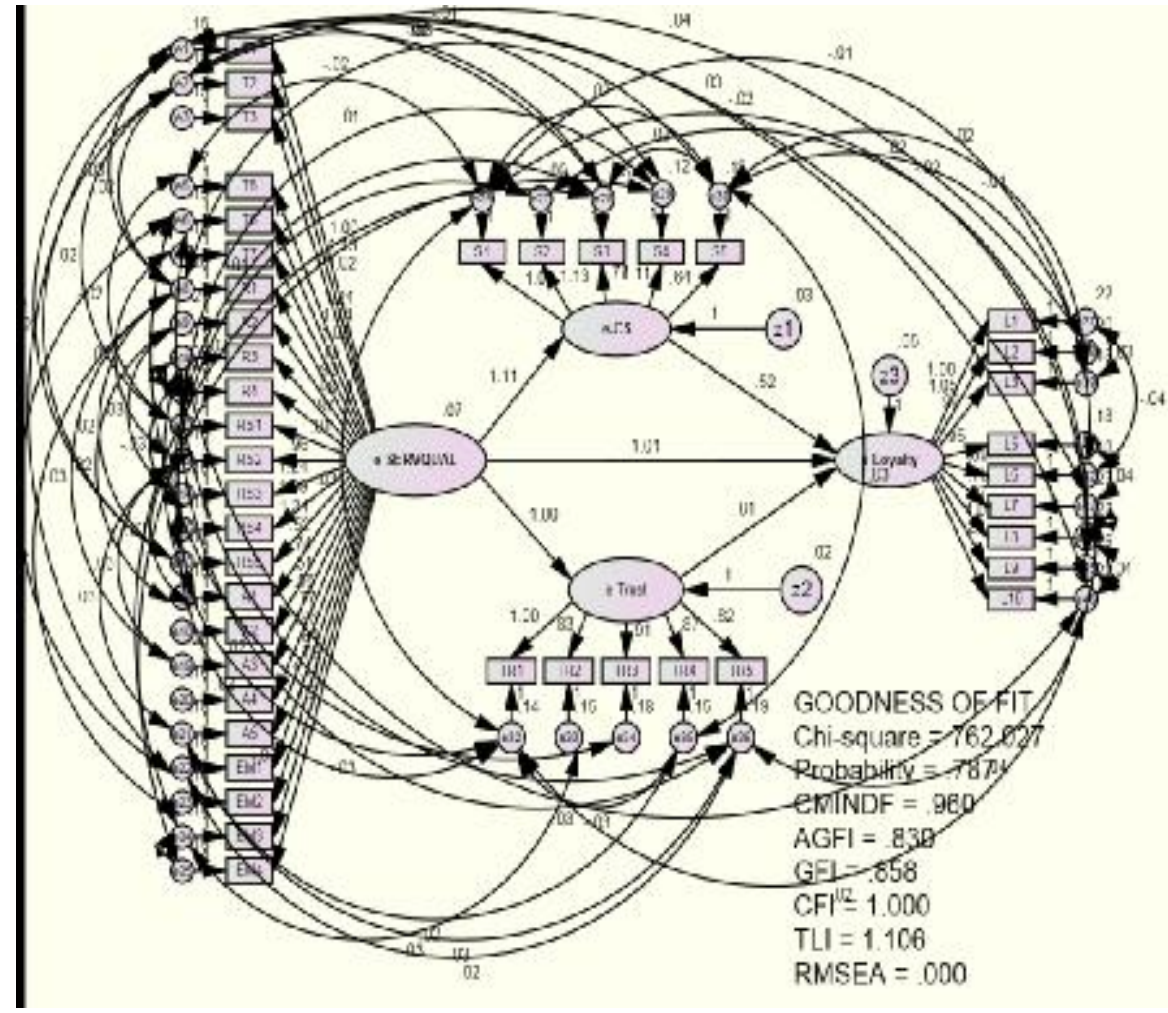

Gambar 4. Model Struktural (SEM) setelah di-Modifikasi

Seperti yang ditunjukkan dalam gambar 4, nilai chi-square harus fit (nilai probabilitas $>0,05$ ) terpenuhi dengan nilai probabilitas sebesar $0,787>0,05$, dan diiringi pengukuran fit model lainnya yang telah dinyatakan fit. Secara overall atau keseluruhan dari enam pengukuran goodness of fit model dinyatakan fit.

\section{Hasil Empiris}

Analisis kausalitas dilakukan guna mengetahui hubungan antar variabel. Pada penelitian ini diharapkan dengan adanya pengujian kausalitas dapat mengetahui pengaruh yang terjadi antara variabel eksogen dengan variabel endogen. Adapun hasil selengkapnya dari tiap hubungan akan diuraiakan pada tabel sebagai berikut:

Tabel 2. Hasil Pengujian Hipotesis

\begin{tabular}{|l|l|l|l|c|c|c|}
\hline \multicolumn{3}{|c|}{ Variable } & Estimate & S.E. & C.R. & P \\
\hline Kepuasan & $<---$ & $\begin{array}{l}\text { Kualitas } \\
\text { Pelayanan } \\
\text { Kepercayaan }\end{array}$ & 1.112 & .199 & 5.578 & $* * *$ \\
Kualitas & & 1.004 & .194 & 5.164 & $* * *$ \\
Lelayanan & 1.004 & & \\
Loyalitas & $<---$ & Kepuasan & .523 & .260 & 2.009 & .044 \\
& $<---$ & Kepercayaan & .810 & .378 & 2.144 & .032 \\
\hline
\end{tabular}




\begin{tabular}{|l|l|l|l|l|l|c|}
\hline \multicolumn{3}{|c|}{ Variable } & Estimate & S.E. & C.R. & P \\
\hline Loyalitas & $<---\begin{array}{l}\text { Kualitas } \\
\text { Pelayanan }\end{array}$ & -1.014 & .574 & -1.766 & .077 \\
\hline
\end{tabular}

Sumber: data primer diolah, 2012

Ket: ${ }^{* * *} \ddagger$ Berpengaruh pada level signifikansi $0,001(\%)$.

Berdasarkan hasil pengujian pada tabel 2, menunjukkan bahwa hubungan (jalur) Kualitas Pelayanan berpengaruh signifikan positif terhadap Kepuasan dengan perolehan nilai C.R sebesar 5,578 , nilai estimate sebesar 1,112 , dan nilai probabilitas sebesar $0,000<0,001$.

Berdasarkan hasil pengujian kausalitas yang terangkum pada tabel 2 diperoleh bahwa hubungan Kualitas Pelayanan terhadap Kepercayaan berpengaruh signifikan positif dengan perolehan nilai C.R sebesar 5,164, nilai estimate sebesar 1,004, dan nilai probabilitas sebesar $0,000<0,001$.

Berdasarkan hasil pengujian kausalitas yang terdapat pada tabel 2 maka hubungan Kepuasan terhadap Loyalitas berpengaruh signifikan positif dengan perolehan nilai C.R sebesar 2,009, nilai estimate sebesar 0,523 dan nilai probabilitas sebesar 0,044<0,05.

Berdasarkan hasil pengujian kausalitas hubungan Kepercayaan terhadap Loyalitas memiliki hubungan yang signifikan, hal tersebut dapat dilihat pada perolehan nilai C.R sebesar 2,144 dan nilai estimate sebesar 0,810 , serta nilai probabilitas sebesar 0,032<0,05.

Berdasarkan hasil pengujian kausalitas yang terangkum pada tabel 2 diperoleh hubungan Kualitas Pelayanan terhadap Loyalitas tidak memiliki hubungan yang signifikan, karena nilai signifikansi memiliki nilai probabilitas $0,077>0,05$ (taraf signifikansi 5\%).

Tabel 3. Hasil Pengujian Analisis Direct Effect, Indirect Effect dan Total Effect

\begin{tabular}{|c|c|c|c|c|c|}
\hline \multicolumn{3}{|c|}{ Hubungan Variabel } & \multicolumn{3}{|c|}{ Pengaruh ( $\lambda$ atau $\beta)$} \\
\hline \multicolumn{2}{|c|}{ Dependen } & Independen & Langsung & Tidak & Total \\
\hline Kepercayaan & $<---$ & & 1.004 & & 1.004 \\
\hline Kepuasan & $<--$ & Kualitas & 1.112 & & 1.112 \\
\hline Loyalitas & $<---$ & & -1.014 & 1.396 & 0.381 \\
\hline Loyalitas & $<---$ & Kepercayaan & 0.810 & & 0.810 \\
\hline Loyalitas & $<---$ & Kepuasan & 0.523 & & 0.523 \\
\hline
\end{tabular}

Berdasarkan rangkuman tabel 3 jalur hubungan yang memiliki nilai menunjukkan nilai koefisien jalur baik koefisien tertinggi adalah hubungan secara langsung maupun tidak langsung Kualitas Pelayanan dengan Kepuasan yaitu antar variabel. Dalam penelitian ini sebesar 1,112. Sedangkan pengaruh tidak terdapat 4 jalur pengaruh langsung. Hasil langsung yang memiliki nilai koefisien analisis menunjukkan bahwa dari keempat 
jalur tertinggi adalah Kualitas Pelayanan terhadap Loyalitas sebesar 1,396.

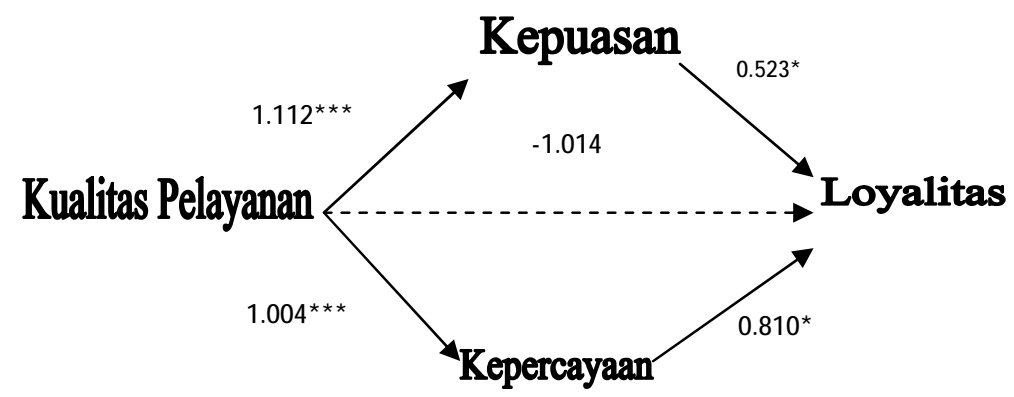

Keterangan :

Gambar 5. Model Kausalitas antar Variabel

* : Berpengaruh pada level signifikansi 0,05(\%).

** : Berpengaruh pada level signifikansi 0,01(\%).

***: Berpengaruh pada level signifikansi 0,001(\%). : Garis hubungan antara variabel memiliki pengaruh yang Signifikan

----- : Garis hubungan antara variabel memiliki pengaruh yang Tidak Signifikan

Dari hasil model kausalitas seperti pada gambar 5 dapat disimpulkan bahwa Kualitas Pelayanan berpengaruh signifikan terhadap Kepuasan ( $\Upsilon=1.112$ : $C . R=5.578$; $p=0,000)$ dan Kepercayaan $(\Upsilon=1.004$ : $C \cdot R=5.164 ; p=0,000)$, sedangkan pengaruh terhadap Loyalitas $(~ \Upsilon=-1.014 ; C . R=-1.766$; $p=0,077)$ dan pengaruh Kepuasan terhadap Loyalitas ( $~(~=0.523 ; C . R=2,009 ; p=0,044$ ) kemudian pengaruh Kepercayaan terhadap Loyalitas ( $\Upsilon=0.810 ; C . R=2,144 ; p=0,032$ ). Hal ini menunjukkan bahwa Kualitas Pelayanan tidak mempunyai pengaruh yang signifikan terhadap Loyalitas. Sedangkan dilihat dari indirect effect Kualitas Pelayanan terhadap Loyalty menunjukkan pengaruh yang positif $(\Upsilon$ $=1.396$ ), hal ini terjadi karena adanya variabel mediasi (Kepuasan dan Kepercayaan) yang mempengaruhi jalur Kualitas Pelayanan terhadap Loyalitas, dari hasil perhitungan total effect, diperoleh bahwa variabel mediasi (Kepercayaan dengan nilai $\Upsilon=0,814>$ Kepuasan dengan nilai $\Upsilon=0,582$ ), sehingga menunjukkan bahwa pengaruh indirect effect variabel
Kualitas Pelayanan terhadap Loyalitas konsumen dimediasi oleh variabel Kepercayaan.

\section{SIMPULAN}

Hasil pengujian hipotesis model struktural dalam penelitian ini dari lima hipotesis empat diterima dan satu hipotesis ditolak. Dapat diambil beberapa kesimpulan antara lain sebagai berikut:

1. Kualitas Pelayanan berpengaruh signifikan dalam meningkatkan Kepuasan. Pelayanan yang dilakukan oleh Saqina.com terbukti dapat meningkatkan kepuasan pelanggannya, diantaranya yaitu dengan selalu mengikuti mode atau tren saat ini, sehingga konsumen merasa senang dan merasa puas (feel satisfied) dengan pelayanan pelayanan yang diberikan oleh Saqina.com.

2. Kualitas Pelayanan berpengaruh signifikan dalam meningkatkan Kepercayaan. Pelayanan yang diberikan kepada pelanggan oleh 
Saqina.com diantaranya dengan menyediakan kontak dari berbagai jenis operator selular yang tersedia di situs sehingga akan memudahkan user melakukan komunikasi, terbukti dapat meningkatkan kepercayaan pelanggan terhadap situs ini.

3. Kualitas Pelayanan tidak berpengaruh langsung secara signifikan dalam meningkatkan Loyalitas. Berdasarkan hasil penelitian ini menunjukkan bahwa secara statistik, pelayanan yang dilakukan oleh Saqina.com tidak dapat meningkatkan loyalitas pelanggan secara langsung, namun dari hasil uji indirect effect antara kualitas pelayanan dengan loyalitas konsumen menunjukkan pengaruh yang signifikan antara keduanya, dan hasil statistik menunjukkan bahwa variabel mediasi Kepercayaan lebih mendominasi jalur pengaruh antara Kualitas Pelayanan terhadap Loyalitas.

4. Kepuasan berpengaruh signifikan dalam meningkatkan Loyalitas. Hasil penelitian membuktikan bahwa kesetiaan pelanggan akan meningkat seiring dengan peningkatan kepuasan konsumen terhadap Saqina.com, jika pelanggan merasa puas dengan pelayanan yang diberikan oleh Saqina.com maka kemungkinan positif bahwa konsumen akan lebih memilih situs ini dibandingkan dengan yang lain.

5. Kepercayaan berpengaruh signifikan dalam meningkatkan Loyalitas. Kepercayaan pelanggan terhadap situs Saqina.com akan meningkatkan loyalitas pelanggan, jika pelanggan bersedia memberikan informasi pribadi pada Saqina.com maka kemungkinan positif pelanggan akan berniat terus menggunakan situs ini.

\section{Keterbatasan}

Keterbatasan dalam penelitian ini diantaranya tidak adanya kendali waktu pengembalian kuisioner sehingga jangka waktu yang cukup lama untuk menunggu reply dan mem follow up responden, juga karena keterbatasan data kontak responden selain email, kurangnya pengetahuan peneliti mengenai format kuisioner online yang tersedia sehingga peneliti hanya menggunakan format attachment office word, dan saran Informasi-informasi yang disajikan oleh Saqina.com sebaiknya lebih teorganisir dengan baik sehingga konsumen bisa lebih mudah dan nyaman dalam bertransaksi, misalnya: mencantumkan secara detail deskripsi produk (misal: jenis bahan, detail ukuran, dlI); mencantumkan tingkat kesesuaian produk di web dengan produk asli; mencantumkan stok produk; menyediakan tahap "Tracking Order" pelanggan dan bagi penelitian selanjutnya diharapkan dapat melengkapi keterbatasan-keterbatasan dalam penelitian ini, diantaranya yaitu: pengembangan variabel dan melakukan perbandingan antara e-commerce.

\section{DAFTAR PUSTAKA}

Armstrong, G. \& Kotler, P. 1996. Principles of Marketing (seventh ed.). India : Prentice Hall.

Bitner, M. J. \& Zeithaml, V. A. 2003. Service Marketing (3rd ed). New Delhi : Tata McGraw Hill.

Cronin Jr, J.J. \& Taylor, S.A. 1992. Measuring Service Quality : A Reexamination and Extension. Journal of Marketing. 56 (7): 5568.

Feick, L. \& Lee, J. 2001. The impact of switching cost on the customer satisfaction-loyalty link; mobile phone service in France. Journal of Service Marketing. 15 (1): 3548.

Gefen, David. 2000. Customer Loyalty in Ecommerce. Journal of The 
Association for Information Systems. Vol 3: 27-44.

Jarvenpaa, S., Tractinsky, N. and Vitale, M. 2000. Consumer trust in an internet store. Information Technology and Management. Vol. 1 No: 1-2: 45-71.

Javad, E.K. 2009. Influential Factors of Customer E-loyalty in Iranian Estores. Master Thesis of Lulea University of Technology. 1 -105.

Mohammad, M.A., Noorjahan, P. 2009. Impact of Service Quality, Trust, and Customer Satisfaction on Customer Loyalty. ABAC Journal. 29 (1) : 24-38.

Moorman, C., Deshpande, R. \& Zaltman, G. 1993. Factors affecting trust in market research relationships. Journal of Marketing. 57 (January): 81-101.

Morgan, R. M. \& Hunt, S. D. 1994. The commitment-trust theory of relationship Marketing. Journal of Marketing. 58 (July): 20-38.

Norizam, K., Nor, A.A. 2010. The Effect of Perceived Service Quality Dimensions on Customer Satisfaction, trust, and loyalty in e-commerce setting : A Cross Cultural Analysis. Asia Pacific Journal of Marketing and Logistics. 22 (3): 351-371.

Oliver, R. L. 1997. Satisfaction: A Behavioral Perspective on the Consumer. New York: McGraw-Hill.

Parasuraman, A., Zeithaml, V.A. \& L.L. Berry. 1988. SERVQUAL : A Multiple Item Scale for Measuring Consumer Perceptions of Service
Quality. Journal of Retailing. 64 (spring) :12-40.

Pearson, N. 1996. Building brands directly: creating business value from customer Relationships. Macmillan Business. 20 (6): 68-82.

Reichheld, F.F., and W.E.J. Sasser. 1990. Zero Defections: Quality Comes to Services. Harvard Business Review. 68 (5): 2-9.

Ribbink, D., Van Riel, A.C.R., Liljander, V. \& Streukens, S. 2004. Comfort your online customer: quality, trust and loyalty on the internet. Managing Service Quality. 14: 446-456.

Singh, J. \& Sirdeshmukh, D. 2000. Agency and trust mechanisms in customer satisfaction and loyalty judgements. Journal of the Academy of Marketing Science. 28 (1): 150-67.

Spreng, R.A. \& Mackoy, R. D. 1996. An empirical examination of a model of perceived service quality and satisfaction. Journal of Retailing. 72 (2): 201-14.

Srini, S.S., Rolph Anderson, Kishore, P. 2002. Customer Loyalty in Ecommerce : An Exploration of its antecedents and consequences. Journal of Retailing. $78: 41-50$.

Sureshchandar, G.S., Rajendran, C. \& Anantharaman, R.N. 2003. The Realtionship Between Service Quality and Customer Satisfaction - A Factor Specific Approach. Journal of Service Marketing. 16 (4): 363-379. 